\title{
AKTIVITAS EKSTRAK KULIT BUAH NANAS (Ananas comosus L.) TERHADAP PERTUMBUHAN Pseudomonas aeruginosa
}

\author{
Alfrida Monica Salasa ${ }^{1^{*}}$ \\ ${ }^{1}$ Jurusan Farmasi Poltekkes Kemenkes RI Makassar \\ *)koresponden: e-mail : alfrida.monica@poltekkes-mks.ac.id
}

DOI: https://doi.org/10.32382/mf.v13i2.786

\begin{abstract}
ABSTRAK
Tanaman Nanas merupakan salah satu tanaman yang banyak diminati oleh masyarakat. Namun, kebanyakan orang hanya mengambil daging buahnya saja sedangkan kulit buahnya dibuang sebagai limbah. Kulit buah nanas mengandung senyawa bromelin, tannin, flavonoid dan alkaloid. Penelitian ini bertujuan untuk menentukan daya hambat ekstrak kulit buah nanas dalam menghambat pertumbuhan Pseudomonas aeruginosa. Kulit buah nanas dikeringkan lalu direfluks dengan pelarut etanol. Lalu ekstrak etanol yang diperoleh diekstraksi lagi menggunakan eter dan n-Butanol sehingga diperoleh ekstrak eter dan ekstrak n-Butanol. Selanjutnya ekstrak yang diperoleh diuji daya hambatnya dengan menggunakan metode difusi agar. Konsentrasi yang digunakan adalah $4 \% \mathrm{~b} / \mathrm{v}$ dengan Ciprofloxacin sebagai kontrol positif dan Na.CMC sebagai kontrol negatif. Diameter zona hambatan rata-rata yang diperoleh untuk ekstrak etanol sebesar 15,33 mm, ekstrak Eter sebesar 8,67 mm, ekstrak n-Butanol 14,33 dan kontrol positif sebesar 25,6 mm. Hasil uji statistik menunjukkan bahwa ekstrak etanol, eter dan n-Butanol kulit buah nanas memiliki aktivitas dalam menghambat pertumbuhan Pseudomonas aeruginosa dan aktivitas terbesar diberikan oleh ekstrak etanol dan ekstrak n-Butanol.
\end{abstract}

\section{Kata Kunci : Ekstrak Kulit Buah Nanas, Daya hambat, Pseudomonas aeruginosa.}

\section{PENDAHULUAN}

Penggunaan obat tradisional di dunia merupakan bagian dari sejarah kebudayaan manusia selama ribuan tahun. Tiap bangsa di berbagai belahan dunia memiliki tradisi pengobatan berbasis bahan alam yang tersedia dilingkungannya. Salah satu bahan alam yang digunakan sebagai obat tradisional adalah buah nanas (Makalew, dkk, 2016).

Masyarakat tidak asing lagi dengan buah nanas karena banyak dikomsumsi sebagai buah segar. Selain itu dalam bidang industri digunakan dalam pembuatan selai, kripik, essens minuman dan pembuatan sirup. Namun masih terbatas pada daging buahnya saja, sering kita jumpai limbah kulit nanas yang selama ini dibuang dan tidak dimanfaatkan, padahal kulit buah nanas sangat bermanfaat bagi kesehatan tubuh. (Hatam, 2013).

Kulit buah nanas mengandung vitamin (A dan C), karotenoid, flavonoid, tannin, alkaloid, kalsium, fosfor, magnesium, besi, natrium dan enzim Bromelin. Bromelin adalah Enzim
Proteolitik yang ditemukan pada bagian tangkai, batang, daun, buah, maupun kulit dalam jumlah yang berbeda. Saat ini limbah yang banyak dihasilkan dari industri buah nanas, umumnya limbah nanas yang berupa batang, kulit, daun dan bonggol belum dimanfaatkan secara optimal, padahal bagian kulit nanas yang biasanya ikut terbuang saat mengupas nanas paling banyak mengandung enzim Bromelain yang dapat menghambat pertumbuhan bakteri. Penelitian ini telah dilakukan dan membuktikan bahwa ekstrak kulit buah nanas dapat menghambat pertumbuhan bakteri Streptococcus mutans, Escericia coli, Vibrio cholera, dan Stapylococcus aureus (Manaroinsong A, dkk, 2015).

Enzim Bromelin merupakan enzim yang dapat menghidrolisis ikatan peptida pada kandungan protein menjadi asam amino. Enzim bromelin memiliki sifat yang mirip dengan enzim proteolitik, yakni memiliki kemampuan untuk menghidrolisis protein lainnya, seperti enzim rennin (renat), papain, dan fisin (Christy, 2012). Selain itu, kulit nanas juga mengandung flavonoid, 
alkaloid, tannin dan steroid (Kalaiselvi, dkk. 2012).

Pseudomonas aeruginosa adalah kuman patogen oportunistik yang dapat menyebabkan keadaan yang invasif pada pasien dengan penyakit kritis maupun pasien yang memiliki tingkat imunitas yang sangat rendah. Umumnya kuman ini sering ditemukan sebagai penyebab infeksi nosokomial di rumah sakit khususnya di Intensive Care Unit (ICU).

Berdasarkan uraian latar belakang tersebut, peneliti tertarik untuk meneliti aktivitas ekstrak kulit buah nanas (Anana comosus L.) terhadap pertumbuhan Pseudomonas aeruginosa. Berdasarkan uraian diatas maka rumusan masalah pada penelitian ini adalah Apakah ekstrak kulit buah nanas (Ananas comosus L.) memiliki aktivitas dalam menghambat pertumbuhan Pseudomonas aeruginosa?

Tujuan dari penelitian ini adalah untuk menentukan daya hambat ekstrak kulit nanas (Ananas comosus L.) dalam menghambat pertumbuhan Pseudomonas aeruginosa.

\section{METODE DAN BAHAN \\ Jenis Penelitian}

Jenis penelitian ini merupakan penelitian eksperimen laboratorium untuk menentukan daya hambat ekstrak kulit nanas (Ananas comosus L.) dalam menghambat pertumbuhan Pseudomonas aeruginosa.

\section{Lokasi dan Waktu Penelitian}

Penelitian ini dilakukan di Laboratorium Biologi Farmasi Jurusan Farmasi Politeknik Kesehatan Kementrian Kesehatan Makassar dan telah dilakukan pada bulan Mei - Juli 2017.

\section{Bahan Uji dan Sampel}

1. Bahan Uji

Bahan uji pada penelitian ini adalah kulit buah nanas yang diambil dari Malakaji Desa Datara Kecematan Tompobulu Kabupaten Gowa.

2. Sampel

Sampel dalam penelitian ini adalah biakan murni bakteri Pseudomonas aeruginosa yang berasal dari Laboratorium Biologi Farmasi Jurusan Farmasi Politeknik Kesehatan Kemenkes Makassar.

\section{Alat dan Bahan Penelitian}

1. Alat yang digunakan

Adapun alat yang digunakan adalah pisau, guntin, autoklaf, oven, cawan petri, gelas ukur, batang pengaduk, erlenmeyer, handscoon, inkubator, jarum ose, kain kasa steril, kapas steril, paper disk, kertas label, kertas saring, lampu spiritus, masker, timbangan, tisu, refluks.

2. Bahan yang digunakan

Bahan yang digunakan dalam penelitian ini adalah kulit nanas yang telah dikeringkan, biakan murni Pseudomonas aeruginosa, natrium agar, etanol $96 \%$, aquadest dan eter.

\section{Prosedur Kerja}

1. Penyiapan Bahan Uji

a. Pengolahan Bahan Uji

Bahan uji yang digunakan adalah kulit buah nanas (Ananas comosus L.). Mula-mula kulit buah nanas dicuci bersih kemudian dipisahkan dari daging buah dan durinya. Setelah itu, kulit nanas dipotong-potong kecil. Potongan kulit nanas kemudian dikeringkan dengan cara diangin-anginkan pada suhu ruang dan terhindar dari sinar matahari langsung. Penjemuran dilakukan beberapa hari, sampai potongan kulit benar-benar kering hingga dihasilkan simplisia kulit buah nanas.

b. Pembuatan Ekstrak

Kulit buah nanas yang telah dibuat simplisia, ditimbang sebanyak 200 gram. Kemudian, dimasukkan kedalam labu alas bulat. Kemudian dituangi cairan penyari etanol $96 \%$ ke dalam labu alas bulat. Simplisia dalam labu alas bulat kemudian di refluks selama 4 jam. Kemudian di saring. Ekstraksi hasil refluks ditampung menjadi satu dan diuapkan untuk memisahkan pelarutnya. Penguapan dilakukan dengan menggunakan rotatory evaporator. Selanjutnya, diuapkan kembali diwaterbath 
hingga didapatkan ekstrak kental kulit buah nanas. Sebagian ekstrak kental yang diperoleh dipisahkah kemudian sisanya di ekstraksi kembali dengan pelarut eter dan nButanol. Ekstrak kering yang telah diperoleh ditambahkan air dan dimasukkan ke dalam corong pisah. Setelah itu ditambahkan eter $20 \mathrm{ml}$. Dikocok, lalu dibiarkan beberapa saat sampai terjadi pemisahan. Ekstrak eter dipisahkan dan ditampung lalu dilakukan pengulangan sampai lapisan eternya jernih. Selanjutnya residu yang diperoleh diekstraksi kembali dengan n-Butanol sebanyak $20 \mathrm{ml}$, dikocok lalu dibiarkan beberapa saat sampai terjadi pemisahan. Lapisan n-Butanol dipisahkan dan ditampung lalu dilakukan pengulangan sampai lapisan nButanolnya jernih. Ekstrak Eter dan ekstrak n-Butanol yang diperoleh diuapkan menggunakan waterbath sampai diperoleh ekstrak kering.

2. Uji Aktivitas Ekstrak Kulit Buah Nanas terhadap pertumbuhan Pseudomonas aeruginosae

Masing-masing Ekstrak etanol, eter dan n-Butanol kulit buah nanas dibuat larutan dengan konsentrasi $4 \%$ b/v. Paper disk direndam dalam larutan bahan uji ekstrak kulit buah nanas, kontrol positif larutan siprofloksasin 50 ppm dan kontrol negatif larutan $\mathrm{Na}$. CMC selama 15 menit kemudian ditiriskan. Disiapkan medium MHA steril yang suhunya $40-45^{\circ} \mathrm{C}$. Dituang kedalam cawan petri steril sebanyak 20 ml, dibiarkan memadat. Setelah itu diulas dengan suspensi bakteri Pseudomonas aeruginosa diatas media MHA tersebut kemudian dibiarkan selama 15 menit. Setelah itu, paper disk diletakkan pada permukaan media dengan jarak satu sama lainnya lebih kurang sama. Diinkubasi dalam inkubator pada suhu $37^{\circ} \mathrm{C}$ selama 1 x 24 jam. Diamati dan diukur zona hambatan, kemudian catat pada lembaran pengamatan.

3. Pengamatan

Pengamatan dilakukan dengan mengukur daerah bening disekitar paper disk dengan menggunakan jangka sorong setelah diinkubasi selama 1 x 24 jam.

\section{HASIL DAN PEMBAHASAN \\ Hasil Penelitian}

Hasil uji aktivitas ekstrak etanol, eter, dan n-Butanol kulit buah nanas dalam menghambat pertumbuhan Pseudomonas aeruginosa dilakukan dengan metode difusi agar dan diperoleh daya hambatan sebagai berikut :

Tabel 1. Hasil pengukuran diameter zona hambatan pada Ekstrak Eter Kulit Buah Nanas terhadap pertumbuhan Pseudomonas aeruginosa.

\begin{tabular}{cccccc}
\hline & \multicolumn{5}{c}{ Diameter zona hambat (mm) } \\
Replikasi & \multicolumn{5}{c}{ Kontrol } \\
\cline { 2 - 6 } & $(-)$ & $\begin{array}{c}\text { Ekstrak } \\
\text { Etanol }\end{array}$ & Ekstrak Eter & $\begin{array}{c}\text { Ekstrak } \\
\text { n-Butanol }\end{array}$ & Kontrol (+) \\
\hline I & 0 & $15 \mathrm{~mm}$ & $9 \mathrm{~mm}$ & $14 \mathrm{~mm}$ & $26 \mathrm{~mm}$ \\
II & 0 & $16 \mathrm{~mm}$ & $9 \mathrm{~mm}$ & $14 \mathrm{~mm}$ & $25 \mathrm{~mm}$ \\
III & 0 & $15 \mathrm{~mm}$ & $8 \mathrm{~mm}$ & $15 \mathrm{~mm}$ & $26 \mathrm{~mm}$ \\
\hline Jumlah & 0 & $46 \mathrm{~mm}$ & $26 \mathrm{~mm}$ & $43 \mathrm{~mm}$ & $77 \mathrm{~mm}$ \\
\hline Rata-rata & 0 & $15,33 \mathrm{~mm}$ & $8,67 \mathrm{~mm}$ & $14,33 \mathrm{~mm}$ & $25,67 \mathrm{~mm}$ \\
\hline
\end{tabular}

Sumber : Data primer Juli 2017

\section{Pembahasan}

Penelitian ini bertujuan untuk menentukan daya hambat ekstrak eter kulit buah nanas (Ananas comosus L.) dalam menghambat pertumbuhan Pseudomonas aeruginosa. Kulit buah nanas terlebih 
dahulu di potong-potong kecil kemudian di keringkan dengan cara di angin-anginkan. Metode penyarian yang digunakan adalah refluks karena kulit buah nanas sendiri memiliki tekstur yang keras dan dengan menggunakan pelarut etanol $96 \%$ karena etanol merupakan pelarut yang dapat menarik senyawa-senyawa kimia yang polar maupun non polar. Ekstrak hasil refluks ditampung menjadi satu dan diuapkan untuk memisahkan pelarutnya. Penguapan dilakukan dengan menggunakan rotatory evaporator selanjutnya dikeringkan kembali di waterbath hingga didapatkan ekstrak kental kulit buah nanas. Ekstrak kental yang telah diperoleh disuspensi dengan air dan dimasukkan ke dalam corong pisah. Setelah itu ditambahkan eter $20 \mathrm{ml}$. Dikocok, lalu dibiarkan beberapa saat sampai terjadi pemisahan. Ekstrak eter yang diperoleh ditampung kemudian dilakukan pemisahn lagi dengan menggunakan eter sampai lapisan eternya jernih. Ekstrak eter yang diperoleh ditampung menjadi satu lalu diuapkan sampai kering. Selanjutnya lapisan air kemudian ditambahkan $20 \mathrm{ml}$ n-Butanol jenuh air lalu dikocok kemudian dibiarkan beberapa saat sampai terpisah. Ekstrak nButanol yang diperoleh ditampung lalu diuapkan sampai kering. Proses pemisahan dilakukan untuk memisahkan senyawasenyawa polar dan non polar dari ekstrak etanol kulit buah nanas. Selanjutnya Ekstrak etanol, eter dan n-Butanol kulit buah nanas iuji aktivitasnya dalam menghambat pertumbuhan Pseudomonas aeruginosa.

Pengujian aktifitas ekstrak kulit buah nanas dalam menghambat pertumbuhan Pseudomonas aeruginosae dilakukan dengan metode difusi agar. Ekstrak etanol, eter dan n-Butanol kulit buah nanas yang diperoleh dibuat konsentrasi $4 \%$ $\mathrm{b} / \mathrm{v}$ dengan suspensi menggunakan Na.CMC karena ekstrak lebih mudah tersuspensi dalam Na.CMC dibandingkan dengan air. Selanjutnya paper disk direndam pada masing-masing ekstrak. Na.CMC sebagai kontrol negatif dan Ciprofloxacin sebagai kontrol positif karena mekanisme kerjanya adalah menghambat aktivitas DNA gyrase bakteri, bersifat bakterisidal dengan spektrum luas terhadap bakteri Gram-positif maupun negatif. Kemudian paper disk diletakkan pada media yang telah diulas bakteri kemudian diinkubasi pada suhu $37^{\circ} \mathrm{C}$ selama 24 jam. Setelah 24 jam, diamati apakah terbentuk zona bening. Zona bening yang terbentuk merupakan zona hambatan. Selanjutnya, diukur zona hambatan yang terbentuk menggunakan jangka sorong dan diperoleh diameter zona hambatan rata-rata untuk ekstrak etanol sebesar 15,33 mm; untuk ekstrak eter sebesar $8,67 \mathrm{~mm}$; dan untuk ekstrak n-Butanol sebesar 14,33 mm. sedangkan untuk kontrol positif sebesar 25,67 $\mathrm{mm}$ dan kontrol negatif sebesar $0 \mathrm{~mm}$ (tabel 1).

Hal ini menunjukkan bahwa ekstrak Etanol, eter dan n_butanol kulit buah nanas dapat menghambat pertumbuhan Pseudomonas aeruginosae. Senyawa kimia yang terkandung dalam kulit nanas yang telah diteliti antara lain mengandung senyawa bromelin, tanin, flavonoid dan alkaloid yang dapat menghambat pertumbuhan bakteri. Senyawa-senyawa tersebut memiliki mekanisme sebagai antibakteri. Enzim bromelin efek yang ditandai dengan efek melunakkan yang disebabkan oleh aktifitas proteolitik yang kuat dari enzim ini, sehingga berpotensi dalam bekerja untuk memberikan pengaruh pada morfologi dinding sel bakteri. Tanin dapat menghambat enzim reverse transkriptase dan DNA topoisomerase sehingga sel bakteri tidak dapat terbentuk. Flavonoid dapat dibagi menjadi tiga yaitu menghambat sintesis asam nukleat, menghambat fungsi membran sel dan menghambat metabolisme energi. Sedangkan, alkaloid yaitu dengan cara menghambat sintesis dinding sel yang akan menyebabkan lisis pada sel, sehingga sel akan mati.

Hasil statististik menunjukkan bahwa nilai untuk tes homogenitas adalah $\mathrm{p}$ : $0,034<0,05$ yang berarti data tidak homogen dan hasil uji distribusi normal menunjukkan nilai $\mathrm{p}: 0,000<0,05$ yang berarti data tida terdistribusi normal. Sehingga uji statistik dilanjutkkan dengan uji Kruskal Wallis dan dialnjutkan dengan uji Mann Whitney

Hasil uji beda dari 5 perlakuan terhadap Pseudomonas aeruginosa dengan uji Kruskal Wallis diperoleh nilai sig. 0,009 $<0,05$. Hal ini berarti bahwa semua perlakuan memiliki perbedaan. Sehingga dilanjutkan dengan uji Mann Whitney untuk menentukan perbedaan antar perlakuan. 
Berdasarkan hasil analisis Mann Whitney menghasilkan perbedaan uji daya hambat antar perlakuan ( Lampiran 5 ). Ekstrak Etanol memiliki aktivitas yang sama dengan ekstrak n-butanol ( sig p: 0,099 > 0,05) sedangkan dengan ekstrak eter memiliki aktivitas yang berbeda dengan ekstrak etanol ( sig p: $0,043<0,05$ ). Ekstrak n-Butanol memiliki aktivitas yang berbeda dengan ekstrak eter (sig p: 0,043<0,05). Ekstrak etanol, eter dan n-Butanol memiliki aktivitas yang berbeda dengan kontrol positif dan kontrol negatif.

Hal ini menunjukkan bahwa ekstrak etanol, eter dan n-Butanol kulit buah nanas memiliki aktivitas dalam menghambat pertumbuhan Pseudomonas aeruginosa dan aktivitas terbesar diberikan oleh ekstrak etanol dan ekstrak n-Butanol.

\section{PENUTUP}

\section{Kesimpulan}

Berdasarkan hasil penelitian dan analisis data dapat disimpulkan bahwa ekstrak etanol, eter dan n-butanol kulit buah nanas memiliki aktivitas dalam menghambat Pseudomonas aeruginosa. Aktivitas terbesar diberikan oleh ekstrak etanol dan ekstrak nButanol.

\section{Saran}

Berdasarkan hasil penelitian yang telah dilakukan maka disarankan untuk melakukan penelitian aktivitas ekstrak etanol dan n-Butanol kulit buah nanas terhadap bakteri dan jamur lain.

\section{DAFTAR PUSTAKA}

Bangun, A. 2012. Ensiklopedia Tanaman Obat Indonesia. Penerbit IPH. Bandung.

Christy. 2012. Pengaruh Proses Pengeringan dan Imobilisasi Terhadap Aktivitas dan Kestabilan Enzim Bromelain dari Buah Nenas (Ananas comosus (L) Merr). Makassar : Jurusan Teknologi Pertanian Fakultas Pertanian Universitas Hasanuddin.

Elliott Tom, dkk. 2013. Mikrobiologi Kedokteran \& Infeksi. Edisi 4. Jakarta. EGC. Judul Asli : Lecture Notes Medical Micribiology \& Infection.
Hatam, dkk. 2013. Aktivitas Antioksidan dari Ekstrak Kulit nanas (Ananas comosus L.Merr). Program Studi Farmasi Unstrat Manado. Jurnal Ilmiah Farmasi-Unstrat, Vol. 2, No.0,1 Hlm.8-12.

Kalaiselvi, dkk. 2012. Occurence of Bioactive Compounds in Ananus comosus $(L)$ : A Standardization by HPTLC. Asian Pacific Journal of Tropical Biomedicine, S1341-S1346.

Makalew A. J. M, Edward Nangoy, dan Pemsi M. Wowor. (2016). 'Uji Efek Antibakteri Air Perasan Daging Buah (AnanasComocuus L) Terhadap Bakteri Klebsiella Pneumoniae". Jurnal e-Biomedik (eBm),4,1.

Manaroinsong A, dkk. 2015. Uji daya hambat ekstrak kulit nanas (Ananas comosus L.) terhadap bakteri Staphylococcus aureus secara IN VITRO. Jurnal Ilmiah Farmasi Vol.4, No.4, Hlm.27-33

Plur. 2010. Analisis Usaha Pemanfaatan limbah Kulit Nanas Menjadi Minuman. Artikel Teknologi Pangan. Diakses pada tanggal 2 Mei 2017, http://www.gubuktani.com.

Radjid M. 2010. Buku Ajar Mikrobiologi. Panduan Mahasiswa Farmasi dan Kedokteran. Jakarta, EGC.

Tochi, dkk. 2008. Therapeutic Application of Pineapple Protease (Bromelain): A Revew . Pakistan Journal of Nutrition, 7(4): 513-520. 